\title{
Introduction: Meanings of Community in Medieval Eurasia
}

\author{
Walter Pohl
}

The present volume deals with ways in which medieval Eurasian communities were shaped, both by social practice and by writing about them. Which "visions of community", which actions and interactions made them seem meaningful? The book presents case studies from three different religious spheres: Christian Europe, Islamic South Arabia and Buddhist Tibet, and explores comparative perspectives between them. What impact did the ascent of these three religions to a hegemonial position have on these macro-regions? How did they affect the construction, affirmation or transformation of particular communities? Transcultural comparison offers fascinating perspectives to explore these issues, to pose new questions in disciplinary contexts, and to discover unexpected parallels and differences through close interdisciplinary cooperation. The studies in this volume are results of a large collaborative project in Vienna, the SFB (Spezialforschungsbereich) F42-G18 "Visions of Community. Comparative Approaches to Ethnicity, Region and Empire in Christianity, Islam and Buddhism, 400-1600 CE" (VISCOM) funded by the Austrian Research Fund (FWF), which started in 2011. ${ }^{1}$ The papers collected here were prepared in interdisciplinary working groups, presented at a conference in November 2013 and successively reworked, discussed and, as far as possible, linked with each other. This volume thus offers a selection from the broader range of research carried out in VIscom. A section of the conference that dealt with the social meaning of apocalyptic visions and the significance of the end of times in Christianity, Islam and Buddhism will be published separately. ${ }^{2}$

VISCOM also addresses problems of comparative methodology, and a first collection of articles on the subject was published in a thematic issue of History and Anthropology in 2014..$^{3}$ Wide-ranging comparison on a Eurasian scale has become a hot topic in Medieval Studies rather recently. ${ }^{4}$ It has opened up

1 http://www.univie.ac.at/viscom/index_viscom.php. See also the proceedings of an exploratory conference: Pohl/Gantner/Payne, eds., Visions of Community.

2 Wieser, ed., Making Ends Meet.

3 Thematic issue "Visions of Community", History and Anthropology 26,1 (2014), edited by Gingrich/Lutter.

4 An important forum is The Medieval History Journal, published since 1998.

(C) WALTER POHL, 2016 | DOI 10.1163/9789004315693_002

This is an open access chapter distributed under the terms of the Creative Commons Attribution-

Noncommercial-NoDerivatives 3.o Unported (CC-BY-NC-ND 3.o) License. 
exciting new perspectives, although much reflection on the rather specific issues of comparative research based on medieval sources is still needed. Especially studies confronting Christian, Islamic and/or Jewish cultural ensembles are moving fast, and have already produced very interesting results. ${ }^{5}$ The first issue of the open-access journal "Medieval Worlds", a spin-off of the viscom project, collected both exemplary studies and a good number of project reports in the field. ${ }^{6} \mathrm{~A}$ lot of empirical study has been done in conjunction with Michael Borgolte's Institut für vergleichende Geschichte Europas im Mittelalter in Berlin. ${ }^{7}$ Medievalists can also rely on experiences and theoretical debates in other fields of history. French intellectual esprit has produced a flaming invitation by Marcel Detienne: Comparer l'incomparable, a slender book published in French in 2000 and in English in 2008, synthesizing the results of a project in which ancient Greece was the point of departure for extensive comparison. ${ }^{8}$ The state of the art, mostly in relation to modern history, has been summed up very aptly and systematically by Jürgen Kocka and Heinz-Gerhard Haupt. ${ }^{9}$ The classical works in 2oth-century comparative history, for instance by Barrington Moore Jr., Ernest Gellner, Immanuel Wallerstein, Charles Tilly, or Theda Skocpol have mostly addressed issues of modern or contemporary history. Many of these authors were historical sociologists or influenced by this discipline, such as Max Weber, Michael Mann, Anthony D. Smith or Shmuel Eisenstadt. ${ }^{10}$ Sociological approaches also helped developing many of the theoretical and methodological tools in comparative history, such as the so-called "large-N comparisons" which rely on operationalized variables tested by statistical methods or Boolean algebra. ${ }^{11}$ Medieval studies, not only because of the dearth of quantifiable material for reliable statistics, are more inclined to what has been classed as "small-n comparisons", that is, narrative or process-oriented comparisons based on extensive in-case studies.

See for instance the ERC Advanced Grant projects "RELMIN: The Legal Status of Religious Minorities in the Euro-Mediterranean World (5th-15th centuries)" (John Tolan, http:// www.relmin.eu/); "FOUNDMED: Foundations in medieval societies' (Michael Borgolte, https://www.geschichte.hu-berlin.de/bereiche-und-lehrstuehle/migei-en/forschung/ projekte/foundmed); and Hudson and Rodríguez, ed., Diverging Paths? a volume that resulted from an international cooperation project.

6 Thematic Issue "Approaches to Comparison in Medieval Studies", Medieval Worlds 1 (2015), doi: 10.1553/medievalworlds_no1_2015; www.medievalworlds.net.

$7 \quad$ Borgolte, ed., Das europäische Mittelalter; id., ed., Integration und Desintegration.

8 Detienne, Comparer l'incomparable; English version: Comparing the Incomparable.

9 Kocka/Haupt, "Introduction".

10 For an overview, see Lange, Comparative-Historical Methods, esp. 22-39.

11 Ragin, The Comparative Method. 
That does not mean that we can only deal with historical singularities, and that comparative approaches are better avoided, as has also been argued. ${ }^{12}$ But in many cases, a small number of variables will hardly suffice to explain major historical changes such as the underlying transformations that many contributions in this volume directly or indirectly deal with: the expansion of Christianity, Islam and Buddhism, the dissolution of the Roman Empire, the rise and fall of the Caliphate and the Tibetan Empire. Thus the aim here is not the construction of transhistorical models, but the transcultural comparison of historical processes and phenomena. This approach to comparison poses a number of methodological problems that need to be addressed. A central issue is the fundamentally European design of our conceptual tools. Can we measure Asian cultures by ideas of progress or ideal types constructed from a European perspective? The debate is open, caution is needed, and we certainly need to reflect on the ways in which we design our criteria of comparison.

Comparative approaches have always been important in social anthropology; however, in the 1980s, comparative anthropology became the subject of serious debate. ${ }^{13}$ One reason was that under the influence of post-structuralist currents, the units of comparison in themselves, cultures, social fields or spaces, were deconstructed, and model-building rejected as a method. It was argued that comparison may create the illusion of bounded social entities and thus risk reifying them as coherent units of comparison. Although this critique was often overdone and sometimes almost turned into an automatic reflex towards certain buzzwords or approaches, it was not unfounded. As Andre Gingrich has recently noted, "one of the main failures in the record of anthropological comparison is the temptation to use it for all kinds of universalist theorizing: from evolutionism to diffusionism, and from Marxism to structuralism". ${ }^{14} \mathrm{~A}$ typology that can be applied to all societies is at best so general that it tells us little about them. In recent years, comparative anthropology has made great progress towards a "new diversity" of methods, including historical anthropology. It has acknowledged mid-range theories, as situated between particular and universal, and developed "critical realism" as an alternative to deconstructivism and positivism. As distinct from quantitative methods in the social sciences, "qualitative comparison" characterizes social anthropological fieldwork; it is also adequate to medieval studies. ${ }^{15}$ "Thick comparison" seeks to accommodate an

\footnotetext{
12 E.g. Espagne, "Sur les limites"; cf. Pohl, “Comparing Communities".

13 Gingrich/Fox, Anthropology by Comparison.

14 Gingrich/Thelen, "Comparative Anthropology", 385.

15 Palmberger/Gingrich, "Qualitative Comparison". This approach is of course different from the algorithm-based analysis of variables that Ragin, The Comparative Method, called Qualitative Comparative Analysis (QCA).
} 
inclusive set of informations, not only where they seem relevant for preestablished criteria, but also data that appear to be circumstantial. 16 "Reflexive comparison" takes into account the construction of its comparative criteria and categories, which should be a methodological standard anyway. "Analytical comparison" seeks to identify independent variables by comparing equivalent units, while "illustrative comparison" aims at verifying a pre-conceived theory or model by referring to a number of empirical cases, which is clearly less relevant for the historical studies assembled here. ${ }^{17}$

In historical research, by tradition more compartmentalized than social anthropology, comparison was long attempted along very general terms, comparing ancient and modern empires, "the" Western and the Islamic city, or the spread of world religions in "the axial age". A critique of such inclusive concepts mostly came in the context of deconstructivism, and was only embraced by a part of the scholarly community. The critique of reified categories and of implicitly employed, time-worn methodological premises was certainly necessary and has remained fundamental. However, little can be gained by a deconstructive reflex that tends to limit the fields and approaches of research, and to leave little space for comparison or model-building. Comparative research, as a methodologically delicate enterprise, has to face this double challenge from the uncritical use of transhistorical axes of comparison on the one side and hypercritical deconstructivist positions on the other. Debate is open about the methodological chances and pitfalls of historical comparison. ${ }^{18}$ We have to be aware that we are dealing with past "singularities" in the first place, and that aligning them for historical analysis or narrative is bound to reduce their particularity. ${ }^{19}$ It is reasonable to claim, as Chris Wickham has done, that "comparative analysis, as long as it is [...] focusing on elements that are really comparable, and employing conceptual categories which make sense internally, can unlock the door into proper, sophisticated, historical explanation better than any other form of analysis can". ${ }^{20}$ The problem lies in deciding which categories make sense. That mostly depends on the models and typologies on which comparison is based, and that it is supposed to validate. Is it advisable to reduce the multiplicity of past societies to highly-aggregate

16 Scheffer/Niewöhner, eds., Thick Comparison; Gingrich/Thelen, "Comparative Anthropology", 388 .

17 Scheidel, "Introduction", 5.

18 For an overview, Kocka/Haupt, "Introduction".

19 Chakrabarty, Provincializing Europe, 56, sees "singularities" as resisting assimilation into historicist discourse and Eurocentric master narratives.

20 Wickham, "Historical Transitions", 19-20. 
typologies? Kocka and Haupt propose a balanced view: "While typological comparisons yield considerable benefits, they also create problems. Sometimes, they underestimate the multi-dimensionality, contingency, and openness of historical situations; they marginalize resistance to general trends and cover up the non-realized alternatives that may have been present in historical situations". Paradoxically, as they argue, "the value of comparative typologies lies not least in the way they provoke research and arguments with a critical thrust and thus contribute to the progress of knowledge". 21

Historians are often sceptical of models and typologies. The most accepted way to construct comparisons around generalizations and thus organize a much more complex range of historical phenomena along relatively simple typologies are still Max Weber's “ideal types". Weber (unlike many historians who appropriated his models) regarded ideal types as a heuristic tool, but not as categories that could then be proven or falsified. ${ }^{22}$ This is not to say that Weber's historical-sociological approach cannot be fruitfully employed in historical studies. In a similarly instrumental sense, Weber's approach has, for instance, been advocated for medieval studies by Otto Gerhard Oexle and Chris Wickham; ${ }^{23}$ and David d'Avray, for his survey of Medieval Religious Rationalities published in 2010, chose the subtitle $A$ Weberian Analysis. ${ }^{24}$ Ideal types may be a useful tool for a first structuring of a field of research by basic typologies, not least if wide-ranging comparison is on the agenda. They have the advantage of allowing for model-building with an attention to historical variety; but the goal of research should still not be to accommodate the variety within the model in order to make it comparable, but to use the model to structure a complex field in order to advance beyond the typology. ${ }^{25}$

This is particularly important in comparison beyond Europe. Weber, like many of his successors, operated within a paradigm in which Europe offered the standard model of progress. Other "cultures" were measured by their deviance from this "ideal type". The concept of "culture" had become fashionable in eighteenth-century Europe. ${ }^{26}$ From an enlightened and ethnocentric European perspective, it could make all cultures comparable and therefore manageable. The humanities and social sciences owe fundamental methodologies to this paradigm. It made cultures formally equivalent, but unequal in the state of

\footnotetext{
21 Kocka/Haupt, "Introduction", 7-8.

22 See Weber, "Die Objektivität".

23 Oexle, Die Wirklichkeit; Wickham, "Historical Transitions", 19-20.

24 D’Avray, Medieval Religious Rationalities.

25 Cf. Kocka/Haupt, "Introduction", 8; Pohl, "Comparing Communities".

26 Luhmann, Gesellschaftsstruktur, 145; Geertz, "Kulturbegriff”.
} 
their cultural development, and thus allowed the controlled othering of foreign societies and the comparative description of their cultural and social characteristics from a European perspective of progress. For instance, it promoted the illusion of a coherent Islamic culture with a time-resistant internal logic, essentially locked in its backwardness and intrinsically opposed to a similarly self-identical Christian culture. This perspective has allowed for many forms of Orientalism. Nowadays, "culture" is still often used to distinguish between bounded (often "ethnic") entities and to confine them within the limits of their circumscribed and subaltern cultural identity. At the same time, "culture" with its positive associations of multiplicity and creativity helps to veil the inequality implied in this cognitive pattern, and its European basis. ${ }^{27}$ It is little wonder that nowadays "culture" has begun to feature among the terms that some scholars prefer to avoid.

On the other hand, the "cultural turn" in the 1980s and 1990s has productively unbounded the concept of "culture", which has become the broadest frame of reference for many humanities disciplines. In the process, two previously distinctive theoretical strands converged: the (post-)structuralist and semiotic strand, as represented, for instance, by Claude Levi-Strauss, Michel Foucault or Pierre Bourdieu; and second, the tradition of phenomenology and hermeneutics, for instance, Alfred Schütz, Irving Goffmann, Clifford Geertz and Charles Taylor. Both schools gradually overcame the traditional binary opposition "objective vs. subjective" and became interested in the links between knowledge and social practice. ${ }^{28}$ Both strands had initially privileged a rather homogeneous view of cultural communities, assuming that they generally tended to reproduce themselves by repeating the same modes of cultural practice and by handing down established systems of knowledge and discourse; but more recent concepts allow a more flexible view of communities. ${ }^{29}$ This "transformation of cultural theories" has opened the way for a more nuanced approach to intercultural comparison.

The issue, in any case, is not to avoid the term "culture", but to be cautious about the centripetal logic that may lead to its reification. "Culture" can be used as a descriptive term, but should not become prescriptive; and its explanatory powers may be more limited than we think. To say that people act as they do because of their culture, at best, does not say very much. We have to acknowledge that "cultures" are hybrid in themselves, if to a different degree.

\footnotetext{
27 Noyes, "On Sociocultural Categories"; Chakrabarty, Provincializing Europe.

28 Reckwitz, Die Transformation der Kulturtheorien, 542-80.

29 See History and Anthropology 26,1, ed. Gingrich/Lutter, with the contributions by Gingrich, Lutter and Pohl.
} 
No doubt the early Islamic world was hybrid - a majority of the population in many of its parts was Christian or Jewish. Medieval Christendom was not monolithic either. One possible research perspective, then, is to aim at histoire croisée, and to write entangled histories across presumed cultural divides. ${ }^{30} \mathrm{In}$ many cases, these cultural areas then come to seem more like a continuum, and certainly, the medieval West, Byzantium and the Islamic world may legitimately be pictured as culturally related in many respects. On the other hand, this promising perspective should not obliterate the distances and differences between them. These distances, we come to realize, neither fully correspond to distances on the map (Fatimid Egypt was closer to Norman Sicily than to Byzantine Anatolia) nor to our basic organizing categories (Syrian "miaphysite" Christians were much better linked to Islamic Baghdad than to "dyaphysite" Christian Constantinople). After centuries of ethnocentric othering we should not simply impose the contrary notion upon these "others": saying that all cultures share the same intrinsic hybridity should not imply denying their being different. Recognizing that "cultures" are not natural units of comparison characterized by a common cultural idiom and an inner logic does not obliterate comparison, but to the contrary, makes it more important. Units of comparison will as a rule be more specific, confronting, for instance, particular regions, social groups, institutions or discourses, and rarely inclusive constructions such as "the" Christian West and "the" Islamic world.

This is a methodologically delicate approach if our subject is "Visions of Community", especially if they project the idea of an inclusive "larger social whole", the umma as the community of the faithful or the populus Christianus as the growing body of the followers of Christ. Both worlds were also highly self-referential, and therefore we need to take into account the inclusive visions of community they produced, their representing themselves as unities. Paradoxically, their entangled and competing "visions of community" to an extent represent common ground between the religions of the book. This leads to a number of comparative questions: Who designed and propagated such unifying visions? To what extent did many millions of people settling across one or even several continents perceive of themselves as one community, as Christianitas or umma? How did they relate their real multiplicity to this envisaged higher unity? And in what ways and contexts did Christian or Islamic elites attempt to impose some degree of uniformity on the basis of shared visions? The sacred scriptures were ambiguous, sometimes even contradictory

30 Werner/Zimmermann, "Beyond Comparison". For the relationship between transcultural/transnational history, histoire croisée and comparative history, see Kocka/Haupt, "Introduction", 20. 
about these visions, and none as much as the Christian Bible; thus they offered a multitude of options to develop lines of convergence. It is also difficult to grasp the agency behind the inclusive and expansive strategies, in discourses as in policies. There may have been several levels of meanings and overlapping communities that should be taken into account here, and a dynamic balance of effort and achievement. No doubt the Islamic and Christian worlds need to be kept present as a frame of reference in our research; but their unifying visions were produced in much more specific environments, and then adopted and adapted in a great number of other particular contexts.

It is indicative that Christianity, Islam and Buddhism all converged at some point with empires. The late Roman Empire after Constantine I, the Umayyad and Abbasid Caliphates, and the Tibetan Empire of the eighth to tenth centuries all coincided with a period of expansion of the respective religion, and built on this dynamic. However, the historical episode in which shared hegemonies of empire and religion seemed almost co-extensive, and some kind of common outlook and commitment were propagated, soon passed. Political pluralism replaced the elusive imperial unity, although the latter remained a model for imitation by later polities. Again, the imperial frame of reference is necessary for analysis. And yet, as recent comparative research on empires has demonstrated, the impact of empires needs to be assessed on the ground, and not least, by its differentiated relations to smaller communities in its sway. ${ }^{31}$ VISCOM addresses this field of tension between broad unifying visions and the shaping of more particular communities. Christian, Islamic and Buddhist worlds were always in some ways under construction (and in some cases, also under deconstruction). The modes of their construction are what we are interested in.

The approach taken by Viscom can be seen in the context of other (and equally necessary) options to conduct comparative research. Studies by individual authors still seem to be the most frequent way to address wide-ranging comparison. They have the advantage, and perhaps sometimes the disadvantage, of a clear unifying vision. Such studies are often based on the methods of historical sociology, where they continue lines of research initiated more than a century ago by the ground-breaking work of Max Weber, and whose interest is mainly in model-building and typology. ${ }^{32}$ Alternatively, specialists in one of

31 Morris/Scheidel, eds., The Dynamics of Ancient Empires; Bang/Kołodziejczyk, eds., Universal Empire; Drews, Die Karolinger und die Abbsiden; Gehler and Rollinger, Imperien und Reiche in der Weltgeschichte.

32 Weber, Wirtschaft und Gesellschaft; Smith, The Ethnic Origins of Nations; Mann, The Sources of Social Power. 
the fields involved, who have studied the results of neighbouring disciplines, engage in wide-ranging comparative studies whose horizon is not completely covered by their expertise. The limits of this approach are that relying on secondary literature alone may be problematic. Controversial debates and emerging consensus on certain issues may elude non-specialists. More fundamentally, they may have to confront systematic bias in their material. Much scholarship on Asia was produced with European paradigms in mind; or, more recently, scholars inspired by post-colonial or neo-identitarian positions have tried to reverse them, almost an Orientalism turned upside down. But both "Orientalist" and "counter-Orientalist" attitudes may lead to conclusions that are more pointed than the sources easily support. Interdisciplinary handbooks or conferences are better placed to open a dialogue between disciplines, and to offer first steps to approach new subjects. But once again, in this format comparison mostly has to rely on interpretations that scholars from another field have reached, without engaging much with the ways in which they arrived at them. Only rarely do the routines of academic life offer opportunities for more indepth comparison. This can be achieved in longer-term national or international scholarly networks. ${ }^{33}$ Even more promising are funding schemes for large-scale projects that are provided by the European Union and by some European countries. ${ }^{34}$ These allow actual interdisciplinary work in a team of younger researchers funded by the project and supervised by the Principal Investigators. The chance to pursue our joint research programme in VISCOM is owed to one of these generous funding schemes in Austria.

The experience of the first years of joint research in the "Visions of Community" project is encouraging, but also suggests the need for caution about methodology. It takes some time to realize where the problems are. What have seemed to be fairly obvious parallels and differences between cultural spheres often become much less obvious the closer one looks at them. This is in part due to the differences in the sources and in the state of their transmission and accessibility - while most relevant texts that deal with medieval cities and monasteries in Europe have been edited or are at least accessible in well-archived manuscripts, the South Arabian and Tibetan evidence is only partly known and to an even lesser degree edited. Furthermore, a traditional Eurocentric "world history" has already shaped the field in many respects. For

33 For instance, the British Academy network in Britain "Defining the Global Middle Ages" (http://globalmiddleages.history.ox.ac.uk).

34 For instance, the DFG-funded Cluster of Excellence "Asia and Europe in a Global Context-The Dynamics of Transculturality" at the University of Heidelberg (www .asia-europe.uni-heidelberg.de). 
instance, our image of Tibetan monasteries or Arabian cities has been produced by European scholars since the 19th century—but were Buddhist monasteries "monasteries" in the European sense? And were civic pride and urban autonomy really absent from Islamic cities? Obviously, one has to work through the different layers of Orientalist and gendered perceptions here, and not all comparative models are equally useful in the course of this research. These layers cannot simply be peeled off to arrive at "authentic" interpretations, or ignored in order to operationalize variables.

Sometimes such heuristic sediments also get in the way of understanding the European evidence; "medievalism" has almost matched "Orientalism" in its prejudiced mix of romantic stylization and modernist contempt. ${ }^{35}$ For instance, the Enlightenment model of a separation of religion and state is almost as inadequate for the Frankish realm of the Carolingians (eighth/ninth centuries) as it is for Arabia or Tibet. The same holds true for our scholarly terminology, which has been gradually produced in a Latin/Greek matrix from antiquity to the present day. Are terms such as nation, religion, state, city appropriate for understanding medieval worlds? In this case, the problem is an inverse one. Whereas these terms may be too alien to Asiatic societies to be applied to them without further reflection, the difficulty with using them for the medieval West is that their equivalents in the sources are seductively familiar, "false friends" that suggest misleading analogies. What medieval authors meant by natio or religio is very different from the significance of the modern terms derived from these words. In ancient and early medieval usage, religio means correct cult practice, and not the inner search for transcendental truth or the social field devoted to it. Similarly, fides/faith describes as much the loyalty towards worldly authorities as the belief in God and the truth that he had revealed. And natio rarely indicates anything like our idea of a nation, but most frequently simply the place of origin (which can also be a small town). The terminological problem becomes more complicated by the fact that many modern English translations of Latin texts translate gens, which usually means "tribe", "people" or "ethnic group", by "nation". A non-specialist may easily conclude that nations were already present in the European Middle Ages, but what in fact happens is a terminological confusion between medieval and modern meanings of the term that obscure instead of explaining its conceptual development and multiplicity. That does not mean that we have to avoid the term "nation" in scholarly language altogether; but it should be handled with care. All these loaded terms - nation, state, culture, identity, ethnicity and so on-are important because they indicate key conceptual areas and give 
access to fields of debate and research. They have to be confronted with the terms and their meanings in the society under study, and can thus be historicized. They pose questions rather than giving answers, and represent fields of tension rather than simple labels for a clearly delimited set of phenomena. That is why they cannot be replaced. ${ }^{36}$

The present volume focuses on four comparative issues that constitute its four sections, and which result from extensive interdisciplinary discussions in VIsCOM's transversal working groups. The first section, "Terminologies", explores some of the basic terms for broad inclusive communities in the Latin West and in Early Islamic contexts: the Latin gens (people, often in the sense of ethnic group) and populus (people, mostly in the sense of a political/religious community); and the Arabic umma (the most frequent designation for the community of the believers), jama'a, which, as Rüdiger Lohlker argues, offered alternative ways to grasp the political significance of "Islamic community" in a flexible way; and qabäil and 'ashäir, terms used for "tribes" in South West Arabia. The contributions in this section combine specific sets of examples with a broader outlook. For Latin usage, Gerda Heydemann relies mostly on Christian biblical exegesis from the third to the sixth century. The advantage of this choice is that Christian authors occasionally reflected quite explicitly about the meaning of the terms that they found in the translation of the Bible, which allows better access to some of the ambiguities and changes of the respective semantic fields.

What makes the use of Christian texts as a source for the language of community difficult is that Christian authors did not only use populus Christianus quite consistently for the Christian people (in a definite or indefinite geographical setting); but they also employed gens for the Christians, a word derived from the notion of common origin by birth. Likewise, as the companion paper by Eirik Hovden and Johann Heiss demonstrates, the word umma could also mean both the Islamic community and tribes and peoples (especially in the plural). In the Christian case, some scholars have argued that if gens is used for the Christians then the term cannot have an ethnic meaning. ${ }^{37}$ Yet such a reductionist view of late ancient and medieval terminology clearly impedes any nuanced understanding of the ways in which religious, ethnic and political forms of community were entangled in the period. The comparison with the early Islamic language of community makes this apparent. The descendants of the Prophet's family are a case in point, as Hovden and Heiss show: "The ashräf claimed to carry on the true religious orthodoxy and authority

36 See a forthcoming article by Walter Pohl, "Loaded Terms".

37 Gruen, "Did Ancient Identity Depend on Ethnicity". 
from the Prophet, through the male blood line as individuals making up a group, a concept that fitted well with the way communities at the time were conceived as genealogies". ${ }^{38}$ In the West, Christian uses of the term gens seem to have reflected back on the ethnic uses of the word. ${ }^{39}$ Without a more differentiated understanding of contemporary uses of the terminology of community, our interpretations of the "visions of community" attested to in these contexts will remain schematic. This requires historicizing our terms in two ways: first, attempting to reach a more specific profile of the shifting significance of these terms in particular historical contexts, or even by individual authors; and second, calibrating our modern terms (religious, ethnic, political etc.) with these glimpses of ways in which contemporaries addressed the phenomena that we want to understand.

The second section addresses "Urban Communities". To what degree were urban settlements understood as communities, and how does the sophisticated legal and institutional civic framework of late medieval Europe compare with the cities of South Arabia? One difference between Western European and Asian cities has often been noted since Max Weber: the notion of a civic community regulated by law and administered by autonomous bodies, such as city councils, which was mostly absent from the East. ${ }^{40}$ Indeed, as Heiss and Hovden argue, only under pressure from outside would the many different communities inside South Arabian cities feel and act as a single "city". On the other hand, city statutes, civic liberties, separate legal status as a citizen, privileges for cities and often also elaborate forms of self-representation as a commune play a role in the rise of occidental cities from the eleventh century onwards. However, normative texts that establish legal distinctions do not tell the whole story. The contributions by Elisabeth Gruber and Oliver Schmitt are based on documents more anchored in social practice, such as charters and court proceedings, and therefore present complementary points of view based on network analysis, regional studies and microhistory. Gruber underlines the role of kinship and other networks in late medieval northern Austrian and southern Bohemian cities; the landed nobility also played a role within the cities. Schmitt, on the basis of the exceptionally rich documentation of conflicts in the Dalmatian island town of Korčula in the $15^{\text {th }}$ century, argues that "there were multiple layers of communitarian belonging in late medieval Dalmatian communities", and emphasizes the highly complex fault lines of these societies. Patricians and common people could easily clash, but they also shared

38 Hovden/Heiss, in this volume.

39 Pohl/Heydemann, "The Rhetoric of Election".

40 Weber, Wirtschaft und Gesellschaft, 727-814. 
common interests; the social distance between city and countryside was relative, and also depended on individual social positions and strategies. Where conflicts within Korčula could not be settled, the more distant and abstract notion of "the glorious lordship of Venice" could be invoked or its intervention sought.

This is a level of analysis on which urban settlements in late medieval Central Europe or Dalmatia are comparable to those in South Arabia; but that requires removing several layers of misleading concepts, as Johann Heiss and Eirik Hovden argue. The concept of "the Islamic city" is hardly adequate as it suggests an underlying homogeneity both over a vast geographical range from Cordoba to Delhi, and within urban settlements in which Muslims often constituted a minority among a culturally very heterogeneous population, all the more so in the early Islamic period. Furthermore, the word "city" is very much rooted in Western perceptions, and at the heart of a semantic field implying citizenship, civic autonomy and civilization. Interestingly, the rough Arabic equivalent, madina, also has strong connotations of "civilization" (tamaddun); but the line between urban and other important settlements is not always easy to draw. An important difference between the Western and Arabic areas of study is the notion of freedom linked with Western cities. South Arabian towns were surrounded by free tribesmen and peasants, and city-dwellers could not boast of a special status, while the vast majority of the population in the countryside in many European countries were unfree in some way. However, as Gruber shows, the process by which city dwellers in Europe acquired personal freedom, and the city became a demarcated zone of autonomous jurisdiction, did not proceed at the same rhythm everywhere. There are many promising lines of comparison that can be further explored on the basis of the studies about urban communities presented here: functions of an urban centre, relations with its surroundings, infrastructure and urban topography and, where possible, relative density of settlements, attitudes towards and identifications with communities within and beyond the city.

The third section deals with genealogies as expressions of community. How were genealogical models used to reinforce the sense of identity and the cultural memory of early medieval Christian dynasties, Yemeni tribes, late medieval Catholic monasteries or Buddhist spiritual communities? Genealogical thinking is one of the most pervasive ways in which humans have structured social relations and ordered the world. It can be applied, in a narrower sense, to kinship and descent, but also to a range of other phenomena-as the contributions by Birgit Kellner about the spiritual genealogies of Tibetan Buddhist lamas and by Christian Opitz about the pictorial representations of the filiation of late medieval Christian orders show. A number of important lines of 
comparison can be pursued here. How are genealogies structured formally: as a list, as a straight line of descent, as a complex web of relations, or as a tree? As Opitz remarks, the family tree was a rather rare model in the representation of medieval pedigrees. To what degree did genealogies include women or even female lines? And did genealogies intersect so as to permit the tracing of closer or more distant kinship between families and tribes?

Significant differences emerge between early medieval Europe and the early Islamic world. Daniel Mahoney portrays a cultural context in tenth-century South Arabia where genealogies mattered in many respects, and the scholar al-Hamdānī tried to synthesize a wide range of genealogical knowledge, not without pursuing a certain political agenda. Lineages could be connected with the mythical ancestor of a tribe, which made the notion of common origin of tribes much more visible to its members. The difference from the scarce transmission of genealogical texts in early medieval continental Europe is striking. There, genealogies are mainly transmitted for ruling dynasties, and they can seldom be interconnected (the British Isles, and later Scandinavia, constitute an exception). Individual genealogies were rarely traceable to particular shared ancestors; if at all, a notion of common origin was achieved by means of a distant connection with the sons of Noah. The frequent political uses of ethnicity in the West, and the relative insignificance of genealogical constructions of social relations seem to be in contrast - but as I argue in my contribution to that section, these may be two sides of a coin.

Genealogical thinking did not only help tracing bloodlines, it could also be used as a tool to structure and represent other forms of trans-generational relations, as Birgit Kellner and Christian Opitz demonstrate. Both address spiritual genealogies, if in rather different form. The transfer of knowledge from teacher to pupil, and linked to that the passing-on of spiritual capital between generations within monastic institutions, can be accommodated very well in a genealogical model. This was especially important in the Tibetan Buddhist tradition, where initially the transmission of the correct teachings relied very much on the personal relationship between the teacher and his pupil, whereas in the Catholic West, orthodoxy could to a larger extent be guaranteed by the Church. It is no coincidence that late medieval Catholic orders adapted the genealogical model to show their institutional continuity and filiations. Both Tibetan Buddhists and Latin Christians were convinced that successful spiritual transfer between generations was ultimately due to empowerment by superior forces, whether that was the incarnation of a Bodhisattva or God's grace and the working of the Holy Spirit. And in both worlds, spiritual institutions were deeply entangled with the surrounding world, not least, with aristocratic 
benefactors. In Tibet, rebirth lineages could thus become a system for regulating succession and made it possible to overcome problems of inheritance and biological contingency - if there was no direct heir, the recognition of a reincarnation offered an option to continue a lineage of spiritual masters, but also of aristocratic patrons of the monasteries. In the late medieval West, spiritual succession and aristocratic genealogies were not entangled so deeply, and the institutional continuity in ownership distinguished monasteries from lay landowners. Rather, genealogical representations of the relations between monasteries, or between the saints of the mendicant orders, sought to reinforce their spiritual legitimacy, being directly modelled on the common motif of the Tree of Jesse, an important model for representing genealogies as trees.

The fourth and longest section addresses "Spiritual Communities: Texts, Sites and Interactions"; for a more extensive discussion of its achievements, I can refer to the introduction and the commentaries in this section. In all regions compared in VISCOM, spiritual communities could become centres of learning and knowledge transfer, such as Christian or Tibetan "monasteries" or South West Arabian hijras in Yemen. These hijras were areas of distinct legal status named after the retreat from unjust rule that their inmates, who often claimed to be descendants of the prophet Muhammad's family, had found there. The medieval hijras are an understudied phenomenon, and have rarely been compared to Western or Tibetan monasteries. This comparison, as it turned out, is very useful to help look beneath the apparent parallels of Christian and Buddhist monasticism and address functional elements. At first glance, parallels between these three forms of community impose themselves: localized, self-styled communities, at least notionally bounded against the outside world, focusing on spiritual practice and the transmission of - mostly sacred-knowledge, concerned with the development of religious doctrine, under the protection of surrounding aristocrats or tribal leaders for whom they fulfil religious, legal and social functions, predominantly funded by pious donations, and connected to but also in competition with similar institutions. But the comparison also runs into problems.

Again, terminology poses a problem. The term monastery comes from the Christian tradition, where it coexists with claustrum, cloister, which underlines its boundedness. Already the eighteenth-century Jesuit missionaries in East Asia noticed the striking similarities between Buddhist "monasteries" and Western ones. Tibet, however, has no single term for monastery; apart from gompa there are several other terms which underline different aspects of these institutions. Hijras are in many respects a functional equivalent, but can hardly be called "monasteries" along these lines. It also has to be taken into account 
that all three forms of religious community saw much variation and changed over time, which becomes obvious by confronting eighth/ninth-century and thirteenth/fourteenth-century monasteries in the West.

How can the range of phenomena to be compared be conceptualized and distinguished from similar centres of learning such as cathedral schools or madrasas? What role did the boundedness of these "enclaves of learning" play-how open were the respective communities, legally or pragmatically? In Tibetan Buddhist and European Christian monasteries, membership implied renunciation of the world for life. But that did not impede various contacts with the outside world. Tibetan monks and lamas performed services for the surrounding laity and local rulers and visited their households; similarly, Christian monasteries have been described as "powerhouses of prayer" in a network of exchanges with the surrounding population. ${ }^{41}$

One pragmatic difficulty that arose in our research was the rather different character of the sources, and their very uneven accessibility, which shape our view of these medieval communities. In Tibet as in Yemen, only a fraction of the existent written sources have actually been studied; in both areas, access is currently hampered by the political situation. Early medieval Europe offers mostly well-edited texts, whereas late medieval sources are extremely numerous. A great variety of texts shed light on medieval European monasteries, not least, charters and other documents about their economic basis and their transactions with the outside world, a type of source mostly lacking for the early periods in Yemen and Tibet. What all three cultural spheres have in common are the biographies of founders, members, patrons and holy men, which can broadly be defined as "hagiography". Christian saints' lives often abound in stories about miracles, often also worked at the saint's grave where his bodily relics were revered. Tibetan texts emphasize a saint's previous rebirths and his relations to a master and his spiritual lineage in order to guarantee the purity of spiritual knowledge. The right Islamic tradition, and its defence against other Islamic currents, takes centre stage in many Yemeni biographies. The Asian traditions focus more on the key role of the spiritual teacher than most Western monastic texts. Christian monasteries reflected more about their institution as such, its spiritual practices, its rule and organization and its position in society.

One level of comparison is the role of female spiritual communities, or of female benefactors. The hagiographic production seems to indicate that women attracted much more attention in the monastic sphere in Europe than in the other regions. Many texts deal with female founders and saints, and 
quite a few were demonstrably written by women. Female monasteries could be centres of learning and play a considerable role. Tibetan Buddhism also allowed for the existence of nunneries. In Yemen, women could play a part in the establishment and consolidation of hijra communities, and some are highlighted as beneficiaries, although on the whole they are mentioned rather rarely.

As may have become clear, the present volume does not offer large-scale comparative models; that may be a next step. The contributions demonstrate that it is rarely possible to establish clear causal relations or to "tick boxes" in order to operationalize variables. Differences between terminologies of community, the organisation of cities, the significance of genealogies or the role of "enclaves of learning" are mostly of degree, and none of the forms to be found in any of the macro-regions under comparison are clear-cut in their distinctiveness. But that does not mean that we have to accumulate singularities without attempting to compare them. The authors seek to identify perspectives of comparison, similarities and differences as they emerge from their research in clearly circumscribed fields and on the basis of the sources available. These sources hardly make it possible to answer all the questions we might have. Yet in their specific profile of interests and omissions, we can try to trace attitudes and perceptions of the space and time in which they were written. Medieval visions of community were never complete, they represent discourses that are as interesting for what they say as for what they leave unsaid, and the same applies to the history of their transmission.

The contributors to this volume can therefore historicize modern scholarly concepts by taking such contemporary or retrospective perceptions, in short, "native knowledge" into account. They employ broad and perhaps problematic concepts such as community, ethnicity or religion, with the previous scholarship attached to them, as points of reference, but try to avoid using preconceived schemes of interpretation. Comparison thus departs from a close examination of the relevant sources in the different disciplines involved. The methodological ambition was to make the way in which conclusions were reached transparent for all scholars involved in the comparative effort by means of an interdisciplinary dialogue. In this way, a web of mid-range and low-threshold comparisons can be built up that will gradually support more general hypotheses. It is an intellectually demanding and fascinating venture. The authors hope that readers of this volume will be able to share some of the excitement that they experienced in preparing it. 


\section{Bibliography}

Peter Fibiger Bang and Dariusz Kołodziejczyk, eds., Universal Empire-A Comparative Approach to Imperial Culture and Representation in Eurasian History (Cambridge, 2012).

Michael Borgolte, ed., Das europäische Mittelalter im Spannungsbogen des Vergleichs: zwanzig internationale Beiträge zu Praxis, Problemen und Perspektiven der historischen Komparatistik, Europa im Mittelalter 1 (Berlin, 2001).

Michael Borgolte, Julia Dücker, Marcel Müllerburg, Bernd Schneidmüller, eds., Integration und Desintegration der Kulturen im europäischen Mittelalter, Europa im Mittelalter 18 (Berlin, 2011).

Dipesh Chakrabarty, Provincializing Europe: Postcolonial Thought and Historical Difference (Princeton, 200o).

David L. D’Avray, Medieval Religious Rationalites: A Weberian Analysis (Cambridge, 2010).

Marcel Detienne, Comparer l'incomparable (Paris, 2000); English version Comparing the Incomparable,. trans Janet Lloyd (Stanford, Calif., 2008).

Wolfram Drews, Die Karolinger und die Abbasiden von Bagdad: Legitimationsstrategien frühmittelalterlicher Herrscherdynastien im transkulturellen Vergleich (Berlin, 2009).

Michel Espagne, "Sur les limites du comparatisme en histoire culturelle", Genèses 17 (1994), 112-21.

Patrick J. Geary and Gabor Klaniczay, eds., Manufacturing Middle Ages: Entangled History of Medievalism in Nineteenth-Century Europe (Leiden, 2013).

Clifford Geertz, "Kulturbegriff und Menschenbild (1966)", in Historische Anthropologie, ed. Aloys Winterling (Stuttgart, 2006), 47-66.

Michael Gehler and Robert Rollinger, eds., Imperien und Reiche in der Weltgeschichte: Epochenübergreifende und historische Vergleiche, 2 vols. (Wiesbaden, 2014).

Andre Gingrich and Richard G. Fox, eds., Anthropology: by Comparison (New York, 2002).

Andre Gingrich and Tatjana Thelen, "Comparative Anthropology: Achievements, Failures and Future", Ethnologie française 42, 2 (2012), 385-390.

Andre Gingrich and Christina Lutter, eds., Visions of Community: Comparative Approaches to Medieval Forms of Identity in Europe and Asia. Thematic Journal Issue: HistoryandAnthropology26,1(2014); http://dx.doi.org/10.1080/02757206.2014.930739.

Erich Gruen, "Did Ancient Identity Depend on Ethnicity? A Preliminary Probe", Phoenix 67, 1,2 (2013), 1-22.

John Hudson and Ana Rodríguez, eds., Diverging Paths? The Shapes of Power and Institutions in Medieval Christendom and Islam (Leiden, 2014). 
Mayke de Jong, "Carolingian Monasticism: the Power of Prayer", in The New Cambridge Medieval History, 2: c. 70o-c. 9oo, ed. Rosamond McKitterick (Cambridge, 1995), 622-53.

Jürgen Kocka and Heinz-Gerhard Haupt, "Introduction: Comparison and Beyond: Traditions, Scope and Perspective of Comparative History", in Comparative and Transnational History: Central European Approaches and New Perspectives, eds. Heinz-Gerhard Haupt and Jürgen Kocka (New York, 2012), 1-30.

Matthew Lange, Comparative-Historical Methods (Los Angeles 2013).

Niklas Luhmann, Gesellschaftsstruktur und Semantik (Frankfurt am Main 1999).

Ian Morris and Walter Scheidel, eds., The Dynamics of Ancient Empires: State Power from Assyria to Byzantium (Oxford, 2009).

Michael Mann, The Sources of Social Power 1: A History of Power from the Beginning to A.D. 1760 (Cambridge, 1986).

Dorothy Noyes, "On Sociocultural Categories", Indian Folklife 19, Folklore Abroad: On the Diffusion and Revision of Sociocultural Categories, ed. Dorothy Noyes (April 2005), 3-7.

Otto Gerhard Oexle, Die Wirklichkeit und das Wissen:Mittelalterforschung —Historische Kulturwissenschaft_Geschichte und Theorie der historischen Erkenntnis, eds. Andrea von Hülsen-Esch et al. (Göttingen, 2011).

Monika Palmberger and Andre Gingrich, "Qualitative Comparative Practices: Dimensions, Cases, and Strategies", in The SAGE Handbook of Qualitative Data Analysis, ed. Uwe Flick (Thousand Oaks, Calif., 2013), 94-108.

Walter Pohl, Clemens Gantner and Richard Payne, eds., Visions of Community in the Post-Roman World: The West, Byzantium and the Islamic World, 300-110o (Farnham/ Burlington, 2012).

Walter Pohl, "Comparing communities - the limits of comparison", History and Anthropology 26, 1 (2014), 18-35; http://dx.doi.org/10.1080/02757206.2014.930739.

Walter Pohl, and Gerda Heydemann, "The Rhetoric of Election-1 Peter 2.9 and the Franks", in: Religious Franks, eds. Rob Meens et al. (Manchester, forthcoming).

Charles C. Ragin, The Comparative Method:Moving beyond Qualitative and Quantitative Strategies (Berkeley 1987).

Andreas Reckwitz, Die Transformation der Kulturtheorien: Zur Entwicklung eines Theorieprogramms (Weilerswist 2000).

Edward Said, Orientalism (New York 1978).

Thomas Scheffer and Jörg Niewöhner, eds., Thick Comparison:Reviving the Ethnographic Aspiration, International studies in sociology and social anthropology 114 (Leiden, 2010).

Walter Scheidel, ed., Rome and China: Comparative Perspectives on Ancient World Empires (Oxford, 2009a). 
Walter Scheidel, "Introduction", in Rome and China: Comparative Perspectives on Ancient World Empires, ed. id. (Oxford, 2009b), 3-10.

Anthony D. Smith, The Ethnic Origins of Nations (London, 1986).

Max Weber, Wirtschaft und Gesellschaft: Grundriß der verstehenden Soziologie, ed. Johannes Winckelmann, $5^{\text {th }}$ rev. ed. (Tübingen, 1980).

Max Weber, "Die Objektivität sozialwissenschaftlicher Erkenntnis", in Max Weber, Gesammelte Aufsätze zur Wissenschaftslehre, ed. Johannes Winckelmann, 6th ed. (Tübingen, 1985), 146-48.

Michael Werner and Bénédicte Zimmermann, "Beyond Comparison: Histoire Croisée and the Challenge of Reflexivity", History and Theory 45 (2006), 30-50.

Chris Wickham, "Historical Transitions: A Comparative Approach", The Medieval History Journal 13, 1 (2010), 1-21.

Veronika Wieser, ed., Making Ends Meet:Cross-Cultural Perspectives on the End of Times in Medieval Christianity, Islam and Buddhism (Berlin, New York, forthcoming). 


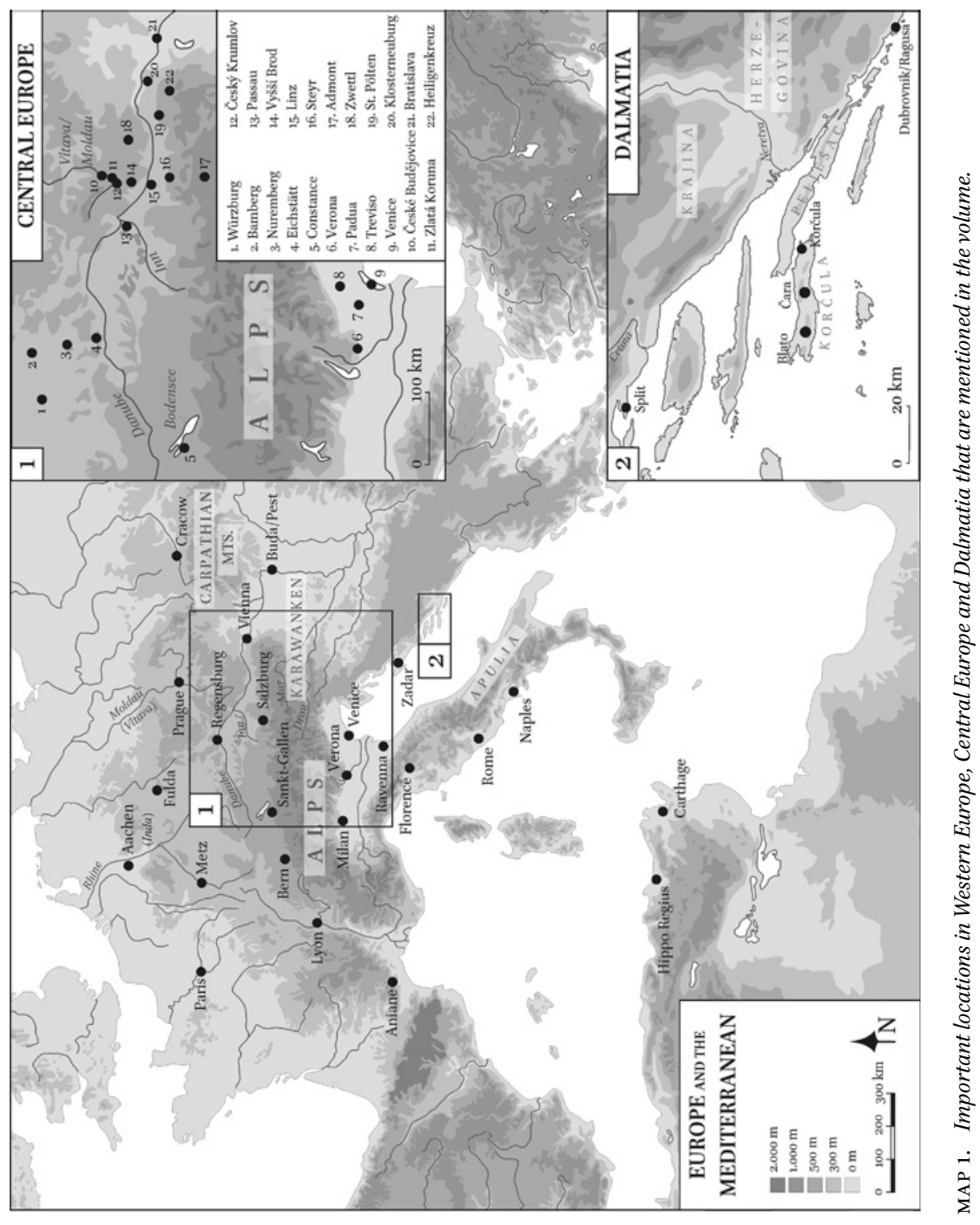




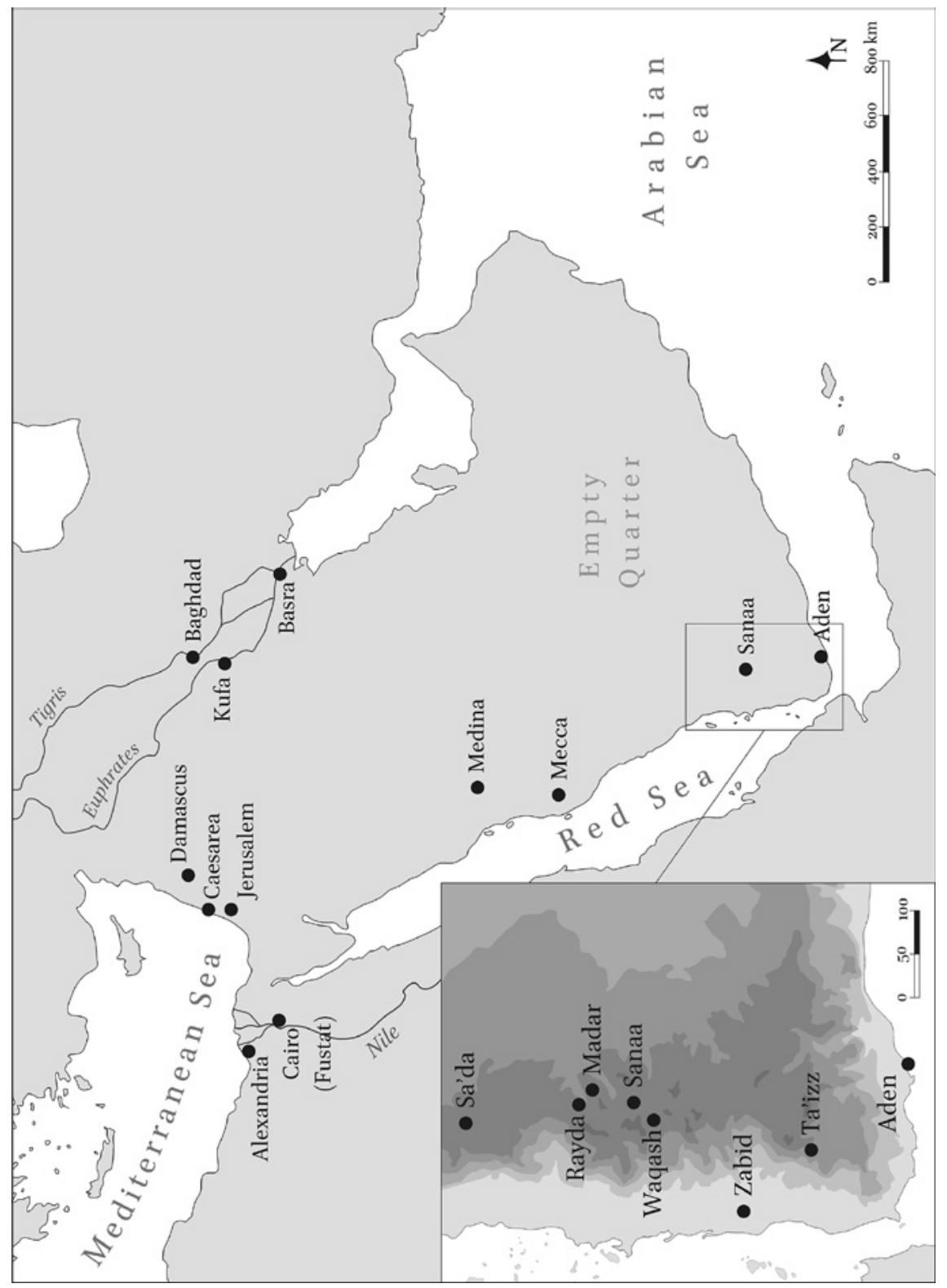

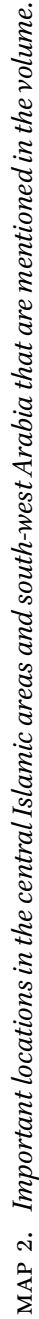




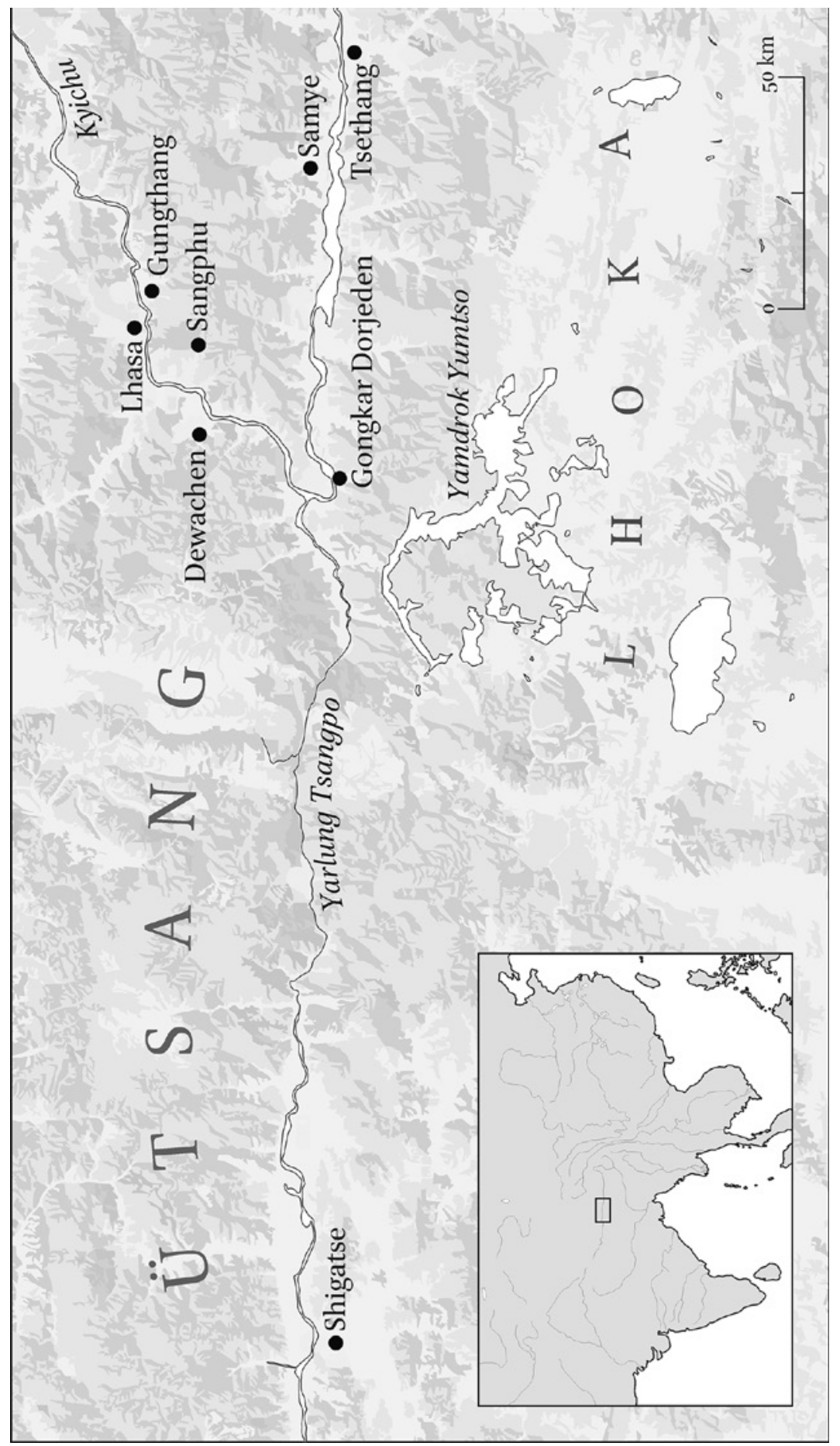

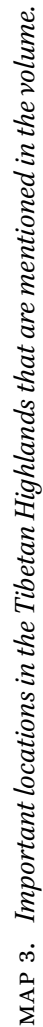

